\title{
The Law of Persons Today: At the Margins of Jurisprudence
}

Edward Mussawir and Connal Parsley

\section{Introduction}

Recent decisions have given legal identity to rivers such as Te Awa Tupua in New Zealand, or the Ganges and Yamuna in India, effectively treating them as having all the rights, duties and liabilities of a legal person. Looking at such cases, in which the enduring fiction of the legal person is extended over an increasingly wide range of referents, we are reminded that this fiction is anything but marginal-especially in the law of any jurisdiction influenced, however indirectly, by Roman jurisprudence. Indeed it remains indispensable to the functioning of almost every species of legal operation, from holding property to liability for criminal prosecution. Little wonder, then, that the person has been marginalised not at all in contemporary scholarship, becoming one of the most enduring conceptualisations of human life, as the 'dispositif' that binds biological and symbolic registers into a single juridical-anthropological institution. Critique and commentary on the person flourishes, in registers from the historical, biopolitical, and political-theological through to every brand of legal studies, be it analytic, normative, interpretative and/or sociological.

This chapter begins from the point of view that this anthropological embedding of the juridical person ought not to be anachronistically attributed to the Roman 'law of persons' in which its craft originated. Rather, we suggest, the well-known Christian metaphysicalization of the juridical person as a moral entity not only adds to but also transforms and displaces that law as a juristic enterprise. What have been marginalised, more specifically, through innumerable shifts, eruptions and evolutions in and beyond juridical culture and its institutions of thought, are Roman law's discrete and self-conscious techniques of shaping the legal person. Whilst there is no doubt that the person remains an eminently flexible institution-demonstrating the ongoing centrality of fiction and invention to modern law-we want to suggest that today the law of persons also exists in relation to another of its modern products: a naturalised conception of the person. When it comes to address a human subject, we suggest, law's technical craft appears now to forget its original vocation in order to serve that naturalised image. It is as though there were a split, within modern law of persons, between the technical and the natural registers: On the one hand, such law embraces its technical virtuosity, and on the other, seemingly in response, law seeks to reassure us of its basis in 'natural' human life. Our conclusion, considering that this natural image of the person is itself the historical product of a suite of legal and theological techniques, is that at least in this sphere, legal technique has undergone a significant shift. The story of law of person's marginalisation thus also reveals, in our account, the marginalisation of a certain consciousness of jurisprudence as a craft, art or technique.

We pursue this argument in three parts. First, considering the law of persons 'yesterday', we exemplify the function of the person in Roman law, pointing out its non-metaphysical quality within the juristic 'art'. In the second part, rather than turning to the familiar fate of the person under the influence of church doctrine, we remain in the juridical register to consider the law of persons 
'today'. Here we attempt to show that whilst legal doctrine freely proliferates technical or abstract senses of the person to satisfy the grammar of its actions, it also seems to be a thrall to a naturalised image of the human in whose service it curtails its own potential operations. We pay special attention to the work of Alex Sharpe, which enables us to address the naturalisation of gender as a key example of the limitations on the legal person today. Finally, we move to the law of persons 'tomorrow'. By this, we mean to highlight a contemporary inspiration-and, more cautiously, a critical potential-to be drawn from a return to a casuistic, concrete and immanent conception of the jurisprudential art of crafting the person. Rather than argue for the inclusion of excluded identities within law's categories (thus extending such categories but doing nothing to challenge the often heteronormative construction of the identities it encompasses) what would it mean to return to an 'experimental' law of persons (or a 'profaned' art of fashioning the person, in Giorgio Agamben's sense)? Might this eventually be a path by which to liberate juristic technique to new uses?

\section{The Law of Persons Yesterday}

\section{The Person as invention of Roman jurisprudence}

The origins of what in the Western legal tradition has been called the 'law of persons' (ius personarum) are often traced to its place in the Roman jurisprudence which, as is well known, cast all its civil law under the rubrics of persons, things and actions. ${ }^{1}$ The story of these origins tends to take a familiar trajectory. The concept of persona, it is said, adopted from the Greek prosōpon, the dramatic mask, expresses a fundamental element crucial to an emergent legal science: the difference that is necessary in law in order to separate the identity of a real living subject from that of a purely artificial, fabricated role that is reserved and instituted at the level of juridical existence. In the same way that the dramatic mask doubles the actor with the role played, the legal person is similarly thought as a double of the real person by which one's inner self is contiguously folded upon a purely abstract role set upon the legal stage. In this way, the 'law of persons' is considered to have offered legal science, throughout its history in the West, an account of what is at the same time the most artificial and abstract as well as the most concrete, immediate, innermost and inalienable aspect of an existence lived in relation to law.

To be confronted with the remnants of Roman jurisprudence, however, is to be presented with a far more functional and circumscribed conception of the person than the one we might expect to find at the origins of a concept that has since taken on far-reaching theological, political and philosophical dimensions. When the surviving texts of Roman law give us the summa divisio to the law of persons: that some are free and some are slaves, that of the free some are freeborn and some are freed, that some are in their own power and some in the power of another etc., it is clear that the significance is far from existential. It might be tempting to take these divisions either as a straightforward reflection of a stratified social structure in which the various statuses and conditions of individuals in Roman society are merely defined, confirmed and entrenched in law and legal culture, or

\footnotetext{
${ }^{1}$ This tripartite division, present in the Institutes of Gaius $(1,8)$, was also later enshrined in the Institutes of Justinian $(1,2,12)$. While Gaius's formulation is the earliest known, Fritz Schulz notes that it is likely that a large part of the divisions of these classical texts come from republican sources. Schulz, History of Roman Legal Science, p 64.
} 
alternatively as designating the purely nominal and formal roles that law necessarily maintains in order to construct the grammar of its normative system. Yet, the work of the positive law, just as the work of jurisprudence of an historical period, cannot necessarily be reduced either to a sociologically descriptive record or to a formally abstract system. Law's records are not neutral and the divisions included within it do not necessary reproduce a reality that lies outside of it more than constitute a specific means of acting upon that reality. The real coherence of the Roman law of persons then does not lie in an independently-conceived sociological phenomenon or political 'context' that it evidences or implicates, any more than it is explained by its later theological and philosophical extrapolations and instantiations. Rather, what is essential to this law is its 'technique', its character as a peculiar mode of invention and intervention in the world of norms. The Roman law of persons was inseparable from a juridical art, an ars iuris embedded in the technologies and fictions of law developed to a high degree by the work of jurists.

To approach the law of persons in Roman jurisprudence in the context of its art and technique is also to situate more precisely what kind of thinking and ordering it enabled at a time when it occupied a primary place within the text of jurisprudence. We can acknowledge for example, when it is a matter of the invention of Roman legal science, that the 'person' is not simply an entity, a norm, a pre-existing individual, a subject that the law simply recognises - if not as a totality 'in itself' then at least with this or that condition or attribute which qualifies it or doubles it - but rather a distinct legal operation with a definite juristic function.

\section{The operation of the person in Roman law}

What is this operation of the person in Roman law? It is useful to indicate firstly what kind of operation it was not. The person of Roman law is without many of the complications in which it will find itself enmeshed in its later history: mechanisms by which the rubric of the person became inextricably bound to a transcendent, theological, metaphysical or meta-juridical frame. ${ }^{2}$ In the Roman law of persons there is really no trace of any problems of identity or the 'self', any construction of a problematic of responsibility or inherent value around moral or ethical personhood, not even any direct question of the relation of law to the natural and biological limits of the life of the person. The person is not, as it later becomes through its Christian theologization, primarily an answer to an existential puzzle. By contrast, as we have suggested, the Romans were able to successfully tie the concept of the person to a distinctly juridical outline in which it served a pragmatic transactional purpose. It is a solution, in other words, to a set of more circumspect jurisprudential problems largely concerning the management of estates and inheritance. It is true that in Gaius's Institutes, the material that goes under the title of the law of persons provides a guide to students regarding the lawful modes by which one comes to acquire or to lose the condition of freedom or slavery, the ways of becoming a Roman citizen or a Latin or being precluded from citizenship, the ways in which one comes under the authority or the guardianship of others etc. ${ }^{3}$ It would be easy to view this as an attempt to simply describe the conditions and statuses that, by law, were attached to persons of the Roman world rather than in fact being an attempt to order, through

\footnotetext{
${ }^{2}$ The theological and metaphysical interpretive tradition usually begins with the classical definition provided in Boethius's Liber de Persona et Duabus Naturis, ch. 3.: 'Persona est rationalis naturae individua substantia' (The person is an individual substance of a rational nature). See e.g. Aquinas, Summa Theologica, 1. 29. 1-3.

${ }^{3}$ Gaius, Institutes.
} 
a basic legal science, the persons themselves as juridical types, by genera and species. ${ }^{4}$ We can also observe that nowhere is this law concerned to develop an account of what we would today call the limits of 'personhood' in itself: the question of who can be legally considered a person before the law and who cannot. There is no problem expressed there, in other words, of whether a slave is or is not a 'person' in the sense equivalent for instance to the way we today tend to debate the personhood of animals or artificial intelligence. Yet just as instructive, at the same time, is the fact that the technicism of the Roman jurisprudence excludes altogether any moral inclination, common elsewhere, toward derogating the servile status of the slave. The person of the slave, just as equally as the person of what we would call the 'full' subject of right, paterfamilias, embodies a condition of which the Roman law acknowledges no more than a distinct juridical outline and function in the sense in which this condition was one that was necessary to technically describe in a precise way in order to properly manage a world of normative-administrative transactions. In fact, it is only because the categories of Roman law tend to be taken as metaphysical or dialectical categories rather than purely technical and functional ones that modern thought finds it peculiarly incongruous that the Roman slave could be treated both as 'thing', property (part of a patrimony), and at the same time as 'person'. ${ }^{5}$ Again, the Roman law of persons offers no such metaphysical opposition between person and thing: what interests it are not the natural or political limits of the human being, but the institutional limits of an estate. It is for this reason that there is remarkably little to be said under the Roman title of 'persons' in terms of an outline of what can be considered a 'person in itself', treated for instance from the extreme or sometimes uncertain limits of its birth and death. If there is a casuistry concerning these limits of the person: the beginning and the end of life, the real or constructive moments of birth and death of the person - problems that today give rise to so many debates for example for the relation between law and bioethics - one doesn't find it there. What the law of persons of the Institutes describes is a set of different concerns: the functional place that certain types of person occupy in the work of law and the 'grammar' of its operations. It is a matter, that is, of the formal parameters by which some substance of personality - a personality which of course is very far from anything 'natural', but which concerns a constructed juridical orientation toward city, patrimony, family and so on - may be addressed, affected, precisely circumscribed, technically extended, modified and often directly manipulated. ${ }^{6}$

Indeed, it is precisely the extent of the manipulation of personality allowable within the Roman law that is most remarkable. The Roman law did not mould its persons on a pre-existing biological

\footnotetext{
${ }^{4}$ Fritz Schulz notes the importance of the transposition of a Platonic method of diairesis or divisio to the Roman jurisprudential endeavour. Schulz, History of Roman Legal Science, p 66-69. 'Pomponius informs us,' writes Schulz, 'that Q. Mucius pontifex was the first to arrange the civil law generatim. He cannot have been the earliest lawyer to employ the method, but he was the first to use it for the systematic arrangement of a lawbook.' p 64

${ }^{5}$ The suggestion, often repeated by modern scholars, that in Roman law the slave was not a 'person' or had no personality appears to be an anachronism. W. W. Buckland notes that ' $[t]$ his view seems to rest on a misconception, not of the position of the slave, but of the meaning attached by the Roman lawyers to the word persona.' Buckland, Roman Law of Slavery, $\mathrm{p} 3$.

${ }^{6}$ Roberto Esposito reads these transitions and manipulations of personhood in Roman law as an indication of a mobile threshold to what he calls the 'dispositif of the person': a category that performs its work by encompassing every gradation from 'the potential person as well as the semi-person up to and including the non-person'. Esposito, Dispositif of the person, 24. John Frow also uses the term dispositif to describe the person as 'an evolving apparatus for the shaping of social arrangements. John Frow and Justin Clemens, 'On Personhood in Public Places' (Surpllus, 2013), p 18.
} 
human substrate. Rather as Alain Pottage puts it, it 'fictionalised biology so as to provide the necessary warrant for each of the transactional personae that it invented. ${ }^{7}$ The person was tied so inextricably to the discrete juridical transaction which it supported that it could even go as far as necessitating a logical denaturation of the biological world. This could be seen in the domain of Roman adoption where new modes of filiation were able to be freely forged not only independently of any concept of the union of the sexes, i.e. through the unilateral authority of a sole male citizen, but also outside the imagination of other constraints of biology, such as when an adopter could manipulate the natural order of generations by adopting a grandson to the level of son, or emancipating and then readopting a son to the level of father of another son. These questions of fiction in the Roman law of adoption, by contrast, deeply troubled the later medieval glossators and commentators who tethered it to a naturalistic reinterpretation of the principle that adoption was constructed on the 'imitation of nature'. ${ }^{8}$ Yet it is precisely within the context of these formal transactions and extreme freedoms taken with an order of natural reality that the idea of the person is forged and deployed in Roman jurisprudence, in what Yan Thomas has called its extraordinary 'empire of fiction'. ${ }^{9}$

\section{The juridical art of the person}

Cast in this context, the person as a work of jurisprudence and of juridical art is distinct from the 'anthropological' or 'dogmatic' function which Supiot assigns to law. Such a function might, in some sense, provide a support or guarantee to the identity of the human being as imago dei or institute the subject as a 'self', for example within the process of donning the mask of an ancestor and taking

\footnotetext{
${ }^{7}$ Alain Pottage, 'Unitas Personae: On Legal and Biological Self-Narration' (2002) 14(2) Law and Literature 275308, at 289-290.

${ }^{8}$ While fiction 'had not the slightest derogatory meaning', for the medieval jurists, according to Ernst Kantorowicz, they nevertheless excluded as 'monstrous' the operation of adoption that would make a younger person the father of someone older than himself. See Ernst H. Kantorowicz, 'The Sovereignty of the Artist: A Note on Legal Maxims and Renaissance Theories of Art' in Selected Essays, pp 352-365 at 354. Yan Thomas also notes that these glossators similarly changed the Roman provision that prohibited a castratus (eunuch) to adopt to a caste natus (someone impotent from birth). The Roman provision was originally an exception, a punishment for an act of feminising the body, whereas for the glossators it could only be seen as a limit that the fiction encountered with the world of 'nature' - a nature inherent to the person's capacity to procreate which could not be overcome even by legal fiction. See Yan Thomas, 'Fictio legis: I'empire de la fiction romaine et ses limites médiévales' (1995) Droits 21: 17-63, at 50; Yan Thomas, 'Les artifices de la vérité en droit commun médiéval' (2005) L'Homme 175-176: 113-130, at 125-126.

${ }^{9}$ Yan Thomas, 'Fictio legis: I'empire de la fiction romaine et ses limites médiévales' 21 Droits 17-63. Thomas rejects what we can call the 'conservative' approach to legal fiction, such as Fuller's (See Fuller, Legal Fictions) for example which treats fiction only as a convenient grammatical mechanism for managing the relation between legal change and the preservation of traditional forms. This approach, Thomas mentions, 'fails to emphasize the distance that the law takes ostensibly toward the facts as a means of its action on them' (Thomas, $\mathrm{p}$ 19). Thus, while Fuller can suggest that the 'reality of a legal institution [understood as the social effects of a legal doctrine]... is in no wise affected by the fact that it may be convenient to describe the institution linguistically in fictitious terms (as in the case of adoption)' (Fuller, p 38), Thomas on the contrary invites us to see the originality in Roman fiction as 'a radical manner of constructing juridical institutions at odds with all tangible truth' (Thomas, p 20). From this perspective, it is only by the detour of the medieval reception of Roman law that one can notice the difference that separates a) the commonplace notion today that the law cannot alter the natural order of reality, from $b$ ) the relation or technique by which law is fashioned precisely by means of its departure from the 'reality' that it announces.
} 
up the place reserved for him or her within the order of genealogy and kinship. ${ }^{10}$ Yet the Roman jurisprudence gives an important priority to the technical register in which it fashions its 'persons', and that register doesn't appear to have any necessary hold on the psychic life of individuals or on the ontological structure of the human being. In every case in which it originally appears, as Thomas tells us, 'the unity of the "person" doesn't cover primarily that of a physical or psychological subject. It primarily covers ... the unity of an estate (patrimony)' ${ }^{11}$ It doesn't, in other words, only offer a mirror to the subject within the names and norms of legal order, it offers a workable solution to a set of interpretive problems of legal order: stretching the contour of the strict legal formulation to its limits in order to stabilise it in the extreme situations that would otherwise place it radically in question.

Thomas provides some examples of how the function performed by the 'person' in its juridical sense in Roman law far from guaranteed the identity of any concrete human subject. Taking the situation of a slave who is jointly-owned between two masters ( $A$ and $B$ ) and who, capable of making undertakings on behalf of a master, makes a promise to another slave who belongs only to master $B$, Thomas shows how the person was a solution to a problem rather than a predicate of legal existence. ${ }^{12}$ In this particular situation, the law upholds the obligation for $A$ arising from the promise by distinguishing between two 'persons' within this jointly-owned slave, the person 'slave of $A^{\prime}$ ' who promises and the person 'slave of B' who doesn't. It can only be through the former persona that the promise is effective, since any promise through the latter persona should be void as being made effectively by $B$ to himself (one of his agents to another). The confusion posed (if only for the legal situation) by the natural unity of this individual and the promise uttered in his singular voice is thus cleverly by-passed through the positing of two 'masks', two persons, where it becomes possible for the promise, from the point of view of the law, to have been made by only one of them.

The rubric of the person also comes to resolve the juridical difficulty posed by vacant estates in the Roman civil law, specifically in the formula that makes the 'estate sustain the person of the deceased'. ${ }^{13}$ Hence, it was by virtue of the personification of the inheritance, that the estate did not fall into abeyance upon the death of the owner in the situation where there was no-one to immediately take up possession of this estate. The person of the deceased was fictitiously extended in the estate in order to cover this intermediary period. Similarly, the formula that father and son constitute the 'one person' - a formula that would enjoy a long politico-theological future - was used at first in a narrow and purely juridical context. It was there concerned with the proper interpretation of a testamentary term. A testator had made a testamentary substitution whereby if his son were to die before being able to inherit his share of the estate, the estate would go to the two already appointed heirs as well as an additional third person 'Titius'. The text considers how the estate should be apportioned in this instance. Should the two existing heirs share one half and

\footnotetext{
${ }^{10}$ On this approach to the law of persons see especially Pierre Legendre, 'Hermes and Institutional Structures' in Law and the Unconscious, pp 137-163; Alain Supiot, Homo-juridicus; Marcel Mauss, 'A Category of the Human Mind: The Notion of Person; the Notion of Self', Trans. W. D. Halls in Michael Carrithers, Steven Collins and Steven Lukes (eds), The Category of the Person: Anthropology, Philosophy, History (Cambridge University Press, 1985) pp 1-25. For Legendre the law of persons refers to an institutional structure which 'anticipate[s] the subjective construction of individuals by attributing to them $a b$ intitio the status ... of a person (persona).' (p 142)

${ }^{11}$ Yan Thomas, 'Le sujet de droit, le personne et la nature' (1998) 100 Le Débat 85-107, at 100.

${ }^{12}$ Thomas, Le sujet de droit, pp 98-99.

${ }^{13}$ Ulpian, Disputations, book 7; Digest 41.1.34
} 
Titius the other half? Or alternatively should all three share in equal thirds? It is Ulpian who supposedly helps answer this problem by distinguishing a related case where it was 'Titius, along with his sons, and Sempronius' who were instituted heirs. Here the device of the person comes to the aid the situation, because - father and son being understood as one person - it is possible in the latter case to give preference to the idea that the estate should be divided in two rather than in three or more equal parts, whereas that preference is missing in the former case. ${ }^{14}$

According to Thomas, it is only after its invention in these original, somewhat modest, casuistic patrimonial circumstances, that the 'person' will also come to name and mask, as it seems to do in the Institutes, the subjects themselves, i.e. as the holders of a patrimony as well as those such as sons of a family or slaves that are in some way bound to it. In these examples we glimpse the sense in which the person and the law of persons offer something more, and perhaps also something less than the usual trajectory would have it. Such a trajectory traces the mask of personhood from a primitive ritual use (in socialising the self), through a representative use (in figuring difference between role-player and role), to modelling the abstract juridical entity (subject of right). Whether it is mask and self, actor and role, representative and represented, in all of these formulations the boundaries of the person seem to remain internally confirmed - this is the binding of the biological and symbolic dimensions of homo juridicus that Supiot attributes to legal personality in and after Christianity. ${ }^{15}$ But when we see its role in Roman jurisprudence in thinking a pragmatic yet radically inventive solution to some early problems, it is apparent that the person is fashioned from an idea that is originally indifferent to the confirmation of the boundaries of a naturalistic self. In this jurisprudence there is no mystical-theological significance to the fact that one individual can explicitly sustain multiple persons; multiple individuals can be sustained in the one person; a person may exist outside the realm of its natural biology; it can operate where there is no corresponding real individual, etc. In this 'independence' as one can say - when it seems to rely on no other normative set of assumptions - we see the 'person' operating according to the outline of more modest principle of an inventive technical precision.

\section{The Law of Persons Today}

\section{Proliferation of the doctrinal technicisms of the person}

Regardless of the anthropological transformation of the person to which we have alluded, the raising of its identity to the metaphysical level, contemporary legal reasoning still treats the person as a relatively unhindered technical category. For dealing with many ordinary legal problems, modern judicial reasoning finds itself pursuing a concept of the person that is tied narrowly to the discrete roles it plays on a legal terrain. When such legal reasoning finds it necessary to distinguish between two or more persons, these 'persons' are distinguished not necessarily by their concrete individuality, but rather by the place reserved for a particular legal function or relation. Persons are the masks, in other words, through which it is necessary and possible to think a given juridical relation. A person is a creditor or debtor, plaintiff or defendant, lessee or lessor, owner or possessor, agent or principal and so on, considered not so much from the point of view of their

\footnotetext{
${ }^{14}$ Justinian Code 6.26 .11

${ }^{15}$ Supiot, Homo Juridicus, ix-x, 24.
} 
ontological existence but from the point of view of the role played and the function fulfilled in the world of law. As we know, the distinction between a 'joint-tenant' and a 'tenant-in-common', as two persons, is not necessarily a distinction made between two concrete individuals, even considered purely from the point of view of their existence before the law. Nor is it simply the distinction between two 'roles', as if these roles prefigured some kind of social action performed by a holder of property. Rather it is a distinction between two positions that fulfil discrete juridical functions with respect to the effect that death has on the subsequent vesting of their property interests. Similarly, a 'beneficiary' under a trust, even when the law requires that this person be certain and ascertainable for the trust to be effective, is a person that strictly need not have a physical existence at all other than as a mere contemplation of law, such as with a child that is yet to be born or even conceived. The person of the 'bona fide purchaser for value without notice' may be a concrete individual, but it exists for law only in order to think the limit beyond which an erroneous transfer of property cannot be recovered by the true or original owner.

So long as the law stays within the realm of its own postulates, one has no need whatsoever to look beyond the masks or the names of law - by which it fashions discrete juridical relations - to the 'real life' of persons that might underlie it. In this way, when questions arise such as whether someone is considered an 'agent' and hence whether or not his or her actions bind a principal, this question depends upon almost nothing that is intrinsic to the individual and their identity and everything that concerns the nature of the discrete, outward relation that the individual maintains in the legal affair. In this situation, we thus go from the case, the legal problem, and only afterwards to the 'persons' through which it is possible or necessary to think or resolve that problem and whose individuality is thereby defined by a legal function. It isn't necessary to start with legal persons, taken in the absolute, as categorical, presumptive, fundamental units (like the human as subject of human rights), with all the complex individuality of the human subject, and afterwards to the question of how their rights must be protected or defined. Instead, the person in this jurisprudential sense is a makeshift extrapolation, a piece of craftsmanship before it has anything as fundamental about it as a premise of the legal order or of political theory.

What is striking however is that these distinctively technical juridical outlines of the person, which persist almost effortlessly in modern legal reasoning, by the same token seem to proliferate as well as stagnate within their doctrinal limits without being addressed at the level of the jurisprudential creativity that gives rise to them. There is little recognition of any single jurisprudential rubric under which the legal art and technique of fashioning persons in this way might be properly presented.

One may point, as Ngaire Naffine has done, to certain rival conceptions of legal personality vying contemporaneously for supremacy: on the one hand a strictly legalist conception which treats the person as a pure fiction and a construction of law; on the other a realist conception which ties it to what can be considered 'real' human beings whose essence the person is thought to recognise or replicate. ${ }^{16}$ Naffine rightly warns against foreclosing the fictional flexibility inherent to the legalistic view of the person and being caught thereby by the lure of a stable metaphysical 'paradigm'. This warning is timely, given that much criticism of law has been generated precisely as an attempt to 'thicken' law's conception of the subject - as if justice was to be better served by a law that hews

\footnotetext{
${ }^{16}$ Ngaire Naffine, Who are Law's Persons: From Cheshire Cats to Responsible Subjects' (2003) 66(3) Modern Law Review 346-367; Ngaire Naffine, 'Review Essay: Liberating the Legal Person' (2011) 26(1) Canadian Journal of Law and Society 193-203.
} 
more closely to the 'natural person'; an approach beset with difficulty. Yet what Naffine's taxonomic approach seems to leave out of the picture is that, even within the legalist conception itself, there is a marginalisation of a juridical 'art of the person'. The legalist today takes the person as a stable juristic entity, and personality as a status in its own right: a general capacity to take legal action and to be the abstract bearer of rights and duties. This notion appears to take precedence over what might have remained a more modest and yet creative idiom: one which grafts the person, as an artefact, to certain makeshift arrangements of law and to a projected set of temporary and discrete juristic relations. Only from the former point of view can it be said, as so much overtly political critique has done, that one 'has' or 'doesn't have' legal personality or that it may be 'granted' to some and 'denied' to others.

To the extent, too, that the title of 'Persons' remains in the dominant contemporary arrangements of jurisprudential material in the West, this body of law largely registers - even if one acknowledges it as a mere construction of law - the recognition of the existence of persons and the confirmation of the general conditions of legal capacity and status attaching to them. ${ }^{17}$ It thus typically addresses the beginning (birth) and end (death) of the legal person and the status and conditions that this entity bears either inherently or by virtue of other legal operations upon it. There is relatively little acknowledgement that the juridical crafting of 'persons' is an activity that doesn't just aim to dress up or qualify, for various purposes, what we can call for convenience either its 'metaphysical', 'existential', 'biographical' or 'positive constitutional' substrate.

\section{Naturalisation of the legal person in the name of truth}

It is in this sense that we can speak of a marginalization of a jurisprudence of persons. On the one hand, the modest, functional, juridical art of the person barely seems to merit detailed critical reflection today, especially when it is kept within its ordinary doctrinal confines. The legalists, in this sense, cannot even imagine the technical work of the legal person that they produce as functioning under the figure of a jurisprudence. Yet on the other hand it is an art that also finds itself swiftly disavowed, marginalised and even radically abandoned within those same confines whenever it is confronted with the evidence for a stable, natural or intrinsic basis to the existence of the legal person.

It should be noted that it is not just the officers of legal interpretation - judges and lawyers - who are complicit in this marginalisation of the juridical art of personality today. The natural, psychological, philosophical and sociological sciences seem to acquiesce in a common view of the person which, sculpted in this way, is offered to the regulative instruments of law as a ready-made concrete subject. From this point of view, however expedient the peculiar juridical fictions of the

\footnotetext{
${ }^{17}$ The title of Persons remains present in many civil codes of the civil law tradition. Book 1, Division 1 of Germany's Bürgerliches Gesetzbuch for example files under the title 'Personen' the provisions of legal capacity, residence and the general laws governing associations. Switzerland's 'Personenrecht' in the Zivilgesetzbuch is similarly composed. Book 1 of the French Code Civil 'Des personnes' is organised into civil rights, respect for the human body, use of genetic techniques for the identification of persons, French nationality, records of birth and death, residence, marriage, filiation, guardianship, civil covenants of solidarity and concubinage. The Dutch Burgerlijk Wetboek also groups 'Personen' with family law. Its general provisions include a prohibition on any form of servitude (Art 1:1) and the legal fiction that an unborn child is taken to have been already born as often as its interests require it, but that if it is born lifeless it is deemed to have never existed (Art 1:2). Book 1 of the Italian Codice Civile, titled 'delle persone e della famiglia', similarly groups the person with the family.
} 
person might be in a variety of ordinary juridical settings, these fictions are swept aside in the face of a dossier of evidence for a real person who - even if, like Descartes, we were to forensically doubt every aspect of its existence - remains tied at least to some undeniable kernel of truth. This is not without consequence for the place that the person finds in law. As Pottage observes, the 'peculiar technical and institutional artefact that is the legal person is clothed with attributes that are manufactured by other forms of knowledge and which obscure precisely those characteristics which define law as a specific kind of narrative technique. ${ }^{18}$ When it is all a matter of treating trustees and beneficiaries, owners and bare possessors, agents and principals, purchasers for value without notice and so on today, law can be content with its purely makeshift conception of the person. It makes no apologies for the fact that it is sculpted purely as a functional juridical device. But as soon as there is a legal question that arises over any aspects of the person which disciplines outside law treat today as inherent, as 'givens' - attributes inscribed at the order of truth rather than at the order of institution - then decision-makers seem to baulk at the dangers of bringing this whole person under the auspices of a fragmented juridical fiction. One prefers a mode of reasoning, in other words, that tends to naturalise the person ahead of one that holds to whatever we might retain of its jurisprudential register.

Let's explore a few examples of where this 'naturalised' register for the person become embedded in law today. Thomas and Olivier Cayla drew attention along these lines to the problem posed in those cases which have been brought for wrongful life, specifically the controversy over the Perruche case in France. ${ }^{19}$ In these kinds of cases, the moral and in many situations the juridical reasoning has tended to reveal a prejudice in favour of the naturalisation of the legal person. In refusing to entertain the action of a child born with disabilities who sues for medical negligence, where that negligence meant that the child, who would otherwise have been aborted as a foetus, was instead left to be born disabled, it becomes impossible to think the existence of the legal person (who for instance makes a claim for compensation for a harm associated with his or her disability) separate from the natural, biological existence of that person. Rather, the features of the legal person remain hostage to those of the flesh and blood entity who is the subject of the claim. The jurisdictions in which this action has been denied (which today is the majority) are unwilling to isolate the necessarily fictional legal person, on which the right of action is based, from the natural person whose birth and thus whole existence appears to depend upon the very act of negligence for which they attempt to claim reparation.

One can also point to illuminating examples within the contemporary law relating to questions of gender and the division of the sexes. The marginalisation of the law of persons here tends to have the consequence of flattening sex onto the person almost to the point of taking its place entirely. Gender is treated as though it cannot be the effect of a legal classification but only a 'truth' or 'nature' received independently of any legal function and taken as inseparable from one's natural person. Faced with an array of statutes that treat gender as a legal attribute or qualification for example, what would ordinarily be kept within the functional conception of the legal person seems instead to be abandoned completely in a confusion between sex and gender. Thus, when the courts

\footnotetext{
${ }^{18}$ Alain Pottage, 'Unitas Personae', 285-286.

${ }^{19}$ Thomas focuses on the French Perruche case. See Yan Thomas and Olivier Cayla, Du droit de ne pas naitre: Á propos de l'affaire Perruche (Gallimard, 2002). The action has been denied in the UK and Aust and in a number of US jurisdictions.
} 
are called to deal with certain disputes or controversies that involve gender identity (for instance in cases that concern the validity of marriages, or the authorisation of treatment for transgender minors where the authorisation of law turns on whether the party is, for the purposes of law, 'male' or 'female'), they turn to the production of knowledge of the person by outside disciplines such as psychology, sociology, genetics, medicine and so on. ${ }^{20}$ It is only in the name of these disciplines that the person seems to be able to be addressed with respect to their gender, which law treats as a kind of external referent confirmable at the level of fact and with the aid of expert evidence.

In the example of marriage for instance, even in situations where it is defined in law as being between a 'man' and a 'woman', modern legal thought tends to still treat those persons as if their gender were verifiable somewhere outside the parameters of the institution itself: treating the person not as a juridico-institutional function but variously as either a sociological, biological or metaphysical given that can in turn serve as a juridical referent. Rather than attend to the technical, artificial and functional relation of gender as an attribute of persons who fulfil a lawful position within an institution in other words - a functionalism which might lend the ordinary inventiveness, fiction and flexibility of juridical art to complex civil or familial relationships - modern law instead takes pains to think and to specify the legal operation that will either remove or secure the formal availability of the institution for couples that it must designate for the first time as being 'same-sex'. Here, one can see why the obsession of modern political consciousness with the legality of 'samesex' marriage does not in the least respond to the social problem of heteronormativity: it simply further embeds a naturalisation of gender which was already becoming dominant in its representation of the law of persons. From this point of view, the predominant mode of critique that calls for an outdated law to 'better reflect life' would appear to have limitations both as jurisprudence and as political action.

\section{The legal impersonation of the natural person: $R v$ McNally}

There is one further contemporary example which, we think, serves to illustrate precisely how far this naturalisation of gender to the person is taken in modern legal reasoning: not just in the name of an external regime of truth, but even against it. The recent work of Alex Sharpe has drawn attention, for instance, to the problems in judicial reasoning in cases concerning transgender individuals and specifically to their prosecution for sexual offences in circumstances where the transgender individual has not disclosed their gender history to a sexual partner. ${ }^{21}$ In the case of $R v$ McNally for example, which Sharpe analyses, a transgender individual was convicted of sexual offences on the basis of having deceived a sexual partner about their gender. ${ }^{22}$ In this case, the victim and accused were teenagers who had sustained an intimate online relationship over roughly four years. The accused had used the male name 'Scott' throughout their relationship and generally presented as male. The pair met each other in person and had sex on a number of occasions. The

\footnotetext{
${ }^{20}$ One need not stop at the case of Corbett $v$ Corbett (otherwise Ashley) [1971] 2 All ER 33 for evidence of this 'naturalised' conception of gender in the legal person. Later cases such as Re Kevin (validity of marriage of transexual) [2001] FamCA 1074 in Australia, which pursue the gender relevant to marriage as a question not of biological determinism but broadly as a social commitment to live life in the chosen gender, further delegate the juridical construction to the work of an outside expert knowledge of the 'person'.

${ }^{21}$ Alex Sharpe, 'Sexual Intimacy, Gender Variance and the Criminal Law' (2015) 33(4) Nordic Journal of Human Rights 380-391.

${ }^{22} R$ v McNally [2013] EWCA Crim 1051. The other case the Sharpe focuses on, concerning the conviction of an individual named Christopher Wilson, is unreported.
} 
accused was later charged by police after the victim's mother, suspecting that 'Scott' was in fact a girl, brought a complaint to the notice of the accused's school. In the case itself, the Court of Appeal refused to overturn a conviction, after the accused had pleaded guilty, affirming that a conviction was indeed possible on the version of facts alleged.

Sharpe frames her critique of this case on legal as well as human rights and public policy grounds: highlighting the inconsistency in the narrative of sexual autonomy when it becomes thought in 'absolute' terms. Yet the case is also distinctive for revealing a certain blind-spot around the place and function of the 'person' in jurisprudence. It is as though gender becomes so constitutive of the person that it becomes wholly mistaken for it. Thus, according to the logic and imagination of the judge, it is as if being mistaken as to the person's gender can be considered equivalent to being mistaken as to the very identity of the person themselves: the only plausible reason ultimately why it can be capable of vitiating consent to sex. ${ }^{23}$ Under common law, Sharpe tells us, there are many things that one can fail to disclose about oneself without it vitiating such consent. However, seemingly, failure to disclose one's 'real' gender, in contrast to a failure to disclose some other nonessential fact about oneself such as being HIV positive, ${ }^{24}$ is effectively the same as pretending that one is a different person altogether: someone who the accused imagines the 'victim' would be willing to have sex with, analogous to the situation of the stranger who deceitfully sidles into bed with the woman who he knows was expecting her partner. ${ }^{25}$

What is notable here is that, in response to these cases, rather than taking the relatively circumspect route that one might expect for law - attempting to perceive the legal relation more clearly by abstracting extraneous personal attributes such as the accused's gender identification and outward bodily appearance which are neither essential to the proceedings nor obviously relied upon by the defendant - the courts have seemed to instead implicitly prefer a more extreme solution: to fictively construct a third person, some imagined boyfriend of the victim (who never existed), who the

\footnotetext{
${ }^{23}$ This logic is at least strongly implicit in the reasoning of these cases. If the failure to disclose one's gender or gender history constituted, as the judge in Rv McNally [2013] EWCA Crim 1051 presented it, only a deception as the sexual nature of the act of penetration (para 26), the implication from this would be that the complainant might have reasonably imagined those same acts to be something inherently nonsexual (a kind of medical procedure for example) were it not for becoming aware of the simple and sole circumstance that the accused was presenting as a gender different from their 'natural' gender. On the contrary, the real implication, quite clearly, is that a mistake or deception as to a person's 'natural' gender is taken as equivalent to a mistake or deception as to the very identity of the person with whom the act of penetration takes place, hence as the judge summarises: the victim 'had consented to the sexual acts because she believed she was engaging in them with a boy called Scott.' McNally, para 11.

${ }^{24}$ Sharpe notes that 'the forms of non-disclosure that do not serve to vitiate consent for the purposes of sexual offences in English law range wildly from false declarations of love to HIV+ status.' $p$ 388. Non-disclosure of HIV positive status under this law, he notes, may constitute a non-fatal assault, but not normally vitiate consent in the context of sexual offences. (fn 36)

${ }^{25}$ Although there was no suggestion raised in the McNally case that the acts of the accused fell under the explicit conclusive presumption in s 76 of the Sexual Offences Act 2003 (UK), namely of 'intentionally inducing the complainant to consent by impersonating a person known personally to the complainant', the logic of legal personality in this decision confirms its reliance on this presumption only more strongly. The 'person' cannot be thought in other words through its discrete juridical function but only as attached to a human body that must be considered either naturally male or female. This is why, far from being peripheral to the decision (as the judge in the case asserts), the accusation of 'impersonation' is precisely what appears to become unavoidable in the case of the transgender accused, whether or not there is even any actual 'known' person who can be the subject of impersonation.
} 
defendant can be thought to have effectively impersonated by presenting in a gender different from the one that is 'naturally' his or her own. Only by this detour is it possible for the court to affirm the experience of the 'victim' that consent was never given to sex with that person. Here we can see that the court prefers to think even a completely fictional person of a definite, natural and manifestly unambiguous gender than to offer the benefit of the technical conception of the person, with its ordinary mask of legal abstraction, to an accused whose gender can afford to be kept wholly unproblematised in the proceedings. There is no question here of a legal comprehension of the various social personae, the 'avatars' or 'alter-egos' that the accused had to maintain in the course of an act - whether playfully or otherwise - of deceiving their intended sexual partner. The law of persons as we understand it is not concerned with the distinction of mere roles in which the subject imagines or presents themselves and in which they are imagined and represented by others. It is concerned with the masks under which a particular juridical relation can be thought. In this regard, the court in McNally prefers to maintain the fiction (in order that the legal person remains naturalised in their gender) that the accused and the 'Scott' with whom the victim believed she was having sex are not, as the facts rather plainly confirm, one and the same person. 'Assuming the facts to be proved as alleged,' as Lord Justice Leveson notes, '[the victim] chose to have sexual encounters with a boy and her preference (her freedom to choose whether to have a sexual encounter with a girl) was removed by the appellant's deception. ${ }^{26}$

Sharpe astutely casts this case and the other similar ones as examples of a distinctly transphobic and cisnormative vision of sexual intimacy persisting in the common law reasoning. But we can add that they also show the extreme lengths to which modern judicial reasoning is prepared to go when it comes to gender, consciously or unconsciously departing from a plain reading of the case, precisely in order to keep the ordinary technical figure of the person at the margins. Instead they mobilise just such a technique in the tenuous preservation of a 'naturalised' conception of the person employing the technical art of legal personhood, that is, as a means to deny the very nature of its plasticity and the necessary plasticity of its conception of nature. If there is a blindspot, it is not necessarily that the law lacks the means of recognising something of the inner lives of transgender individuals, a recognition which would include a fundamental acceptance of the singularity of their circumstances and respect for an 'inherent' personality before the law. Instead, it is even the reverse, because in marginalising the technical register of the person at the level of which sex or gender would be treated purely in terms of the narrow juridical function that it serves, the judges are left instead to project and to fill in so many unnecessary details to the blank canvass of this 'naturalised' person and their essentialised 'gender identity'. In short, it is not only in the name of a fundamental 'truth' of nature that the technical and jurisprudential register of the person is marginalised today. It is also apparently by way of certain 'fictions of natural personality': such that even the evident truth is not permitted to get in the way of preserving the supposition that law's person has an essence grounded in a 'naturalised' biology.

\section{The Law of Persons Tomorrow}

Use of the legal techniques of the person

\footnotetext{
${ }^{26}$ McNally, para 26.
} 
Allow us to put forward a hypothesis. The juridical crafting and invention of the 'person' is a work that will continue to go on unabated. Yet, without a definite place reserved for it in jurisprudence, without a distinct jurisprudential rubric under which these modes of invention can be collected, ordered, categorised, investigated, deciphered, critiqued and so on, they will also continue to be consigned to the relative margins, outstripped by a centrality and orthodoxy offered by a now commonplace, naturalised, conception of the person. The work of recuperating something of this jurisprudential rubric is therefore important. It is important not just in terms of the possibility for legal doctrine to find a way, in its own terms, for reflecting upon the techniques and technologies of the person that are very often close to its heart. It is also important from the point of view of a legal critique that seeks not just to expose that doctrine to the implications of its social, political, cultural and historical contexts and contingencies but also, from within, to undo what we might call the intersection of orthodoxies operating between law and the social sciences. To the extent that critical legal scholarship has in a large part seen the need to take a wrecking-ball, if not just to the edifice of the 'legal subject' then also to the strict juridical conception of the person - the abstract formalism of which it has commonly taken as a mask simply for the dominant forms of power - it has also tended to deprive itself of an immanent technical terrain that in fact may turn out to be much to its advantage.

Compared to the work of Roman law, we no longer seem to have the full range of tools and techniques at hand for 'working' on the person, that is, as the product of an aesthetic and jurisprudential enterprise. This impoverishment rears its head not just at the level of law but indeed at all the levels in which the person is fashioned and deployed as a technology of unity and continuity today. It means that we are beholden, as we have suggested, to a 'natural image' of the person: a person ostensibly tied to its own nature and thus separated from the techniques in which it was, at an institutional level, a remodelling of nature. Borrowing Giorgio Agamben's terms, we could say that the legal art of the person has been a collateral casualty of the person's 'sacralisation'. This, of course, means something more than just challenging the now banal claim that the person is sacred. For Agamben, something that is sacer is separated from the realm of human activity into a divine sphere and denied to a simple common use. ${ }^{27}$ But if, condensed into the notion of the person itself is its status as an image-not just as a representation, but also as itself an artefact produced at the level of art or technique-then concealed within the claim that 'the person is sacred' is a double operation. First, it involves the production of this image of the person as 'natural' precisely by the techniques of personhood themselves, such as through the reappropriation of the Roman jurisprudential material for the construction of Trinitarian conceptions of the person: consubstantiality, hypostatic union and so forth. ${ }^{28}$ And second, it involves the concomitant removal of the art of the person qua art - a removal which we see as the plight of the person in modern jurisprudence - leaving behind in law only a kind of technical execution serving the 'natural/sacred' image. It is here that the broader crisis in the stability of the person can begin to be diagnosed: a crisis or anxiety for example about the stability of the referent 'person' outside law, which amounts to an acknowledgement that the person is extremely vulnerable to legal definition/decision (the person is what the law says it is from time to time and case to case), all of which reveals a deep crisis

\footnotetext{
${ }^{27}$ See particularly Giorgio Agamben, Profanations, 73-4, 78.

${ }^{28}$ See Esposito, Dispositif of the Person, 20-21.
} 
or lack of faith in the law itself and its power. ${ }^{29}$ Might it be possible, on the other hand, to clear the anxieties both in the moral tendency toward constantly seeking recognition for the 'real' person behind the abstractions of law as well as in the dogmatic tendency to limit the technical abstractions of legal personality to their narrow specialised domains, preparing the terrain for a more immanent critique and a more flexible interpretive arrangement?

\section{The person as experiment}

Allow us to return to one further example taken from the irreplaceable work of Yan Thomas, concerning the modest casuistic origins of the concept of the 'juristic person'. This analysis provides, if nothing else, a sense in which it may be possible to recollect and win back some of the fragments of a 'law of persons' that we have suggested has tended to be marginalised today. Thomas explains how the concept of the juristic person - the abstract personality normally fictively accorded to collectives such as corporations - had a relatively modest beginning in the medieval debates concerning vacant monasteries. When a monastery had been left completely empty by the death of all of its members and was then later reinhabited by a new community of monks, what was the status of the property? Could the ownership be thought to pass seamlessly from one collective to the next despite the intervening period of abandonment, or did the temporary vacancy leave the continuity of ownership broken and thus absorbed within the papal treasury? Thomas discusses the solutions that were offered by the medieval jurists at the time to deal with this extreme example. Some thought that since the property, having been given to the monks themselves, once left without an owner necessarily reverted to the Pope. Another, Mose of Ravenna, on the other hand, offered a separate makeshift solution to support the opposite view. To prevent the property from falling into abeyance in this way, he suggested that the property was not given to the monks themselves, but to the very walls of the monastery. The walls in effect, installed as a provisional 'owner', managed in this way to extend the continuity of the property beyond the death of the original monks in time for it to be taken up by others. Thomas notes that this expedient later found other figures of support in the Roman law - as we have seen - for example in that which made the estate or inheritance 'perform the function of person', precisely in order to stitch over the perilous legal temporal discontinuities occasioned by death. However what is most notable, according to Thomas, is not the 'idea of personification' itself at play here, associated as it may be with the theologised political metaphors of the Middle Ages, ${ }^{30}$ but the way in which a purely makeshift device of legal reasoning occasioned by an exceptional case, was able to go on and serve as the abstract model, the hypothesis for a more or less complete and self-sufficient institution of the 'juristic person'. It is as though, through the extension of this one narrow and pragmatic fiction to a full range of related scenarios, it had become possible henceforth to view any collectivity as an abstract entity with a continuous juridical existence over time independent of the individual members.

\footnotetext{
${ }^{29}$ Eric Posner for example attempts to set aside the anxieties and fascinations surrounding the process of legal personification by emphasising the purely functional and technical (rather than metaphysical) operation that the person has in law. He is concerned less however with what we might call the 'jurisprudential techniques of the person' than a form of statutory intentionalism that treats the various uses of the term 'person' in law as context-driven, purposive and ultimately ad hoc. See Eric Posner, 'Stop Fussing Over Personhood', http://www.slate.com/articles/news_and_politics/view_from_chicago/2013/12/personhood_for_corporation s_and_chimpanzees_is_an_essential_legal_fiction.html

${ }^{30}$ See Ernst Kantorowicz, The King's Two Bodies.
} 
This kind of narrative should not necessarily be thought as part of a general 'history of the law of persons' let alone a 'general jurisprudence'. It is only from within the very instruments of critique made available to us by law that we can view the emergence of such a concept of the legal person and its preparation for a distinctly jurisprudential vocation. In the example above, we can see that if there is a case history to the law of persons, it is more of a concrete casuistry, a kind of laboratory the site for observing a thoroughly experimental activity - than a doctrinal history that can be situated straightforwardly along a certain line of 'progress'. We can stop short of imagining, for example, that the law of persons can be treated like a stable body of principles whose textual parameters can be traced and represented in a more or less linear fashion: here receding in pace with the advance of a modern liberal project of equality, there remaining only like a vestige of a Roman taxonomy that modern Western law has either more or less internalised or reduced to an unspoken theoretical postulate. The Roman law of persons itself, it should be noted-despite the sedimentary, codified form in which it has been passed down - is no mere historically defined statutory scheme. It is above all a language and cipher for a set of enduring legal techniques. And of course, it is precisely the techniques, the provisional crafting of persons that we see continuing to proliferate in law today but which, being too often restricted to the narrow doctrinal sub-fields in which they are deployed, do not operate under the concerted rubric of a 'law of persons'. This is so even (or perhaps especially) when this law, whether yesterday or today, is also presented to us as an explicit doctrinal category in its own right. 